\title{
PEROLEHAN PERLINDUNGAN HUKUM TERHADAP SUATU PRODUK BERDASARKAN UU NO. 31 TAHUN 2000
}

\author{
Desi Febriani \\ 175100042P, 785567879 \\ Fakultas Komputer \\ desifebriani.student@umitra.ac.id
}

\begin{abstract}
Indonesia adalah salah satu anggota WTO (World Trade Organization) yang di dalamnya menyangkut TRIPs Agrement (Trade Relatred Aspects of Intellectual Property Rights Including Trade Inn Counterfied Goods), wajib mengharmoniskan sistem hukum Hak Kekayaan Intelektual (HKI) dengan mematuhi standar-setndar internasional sesuai TRIPs. Salah satu kewajiban dalam TRIPs Agrement adalah indonesia harus memiliki peraturan dan ketentuan hukum yang dapat melindungi karya-karya di bidang desain industri. Maka di Indonesia pengaturan mengenai perlindungan desain industri diatur dalam UU No. 31 tahun 2000 tentang desain industri.

Menurut ketentuan pasal 1 ayat (1) UU No. 31 tahun 2000 tentang desain industri yang dimaksud dengan desain Industri ialah suatu kreasi tentang bentuk, konfigurasi, atau komposisi garis atau warna, atau garis dan warna, atau gabungan daripadanya yang berbentuk tiga dimensi atau dua dimensi yang memberikan kesan estetis dan dapat diwujudkan dalam pola tiga dimensi atau dua dimensi serta dapat dipakai untuk menghasilkan suatu produk, barang, komoditas industri, atau kerajinan tangan.

Merujuk pada definisi diatas maka, karakteristik desain industri itu ialah suatu kreasi tentang bentuk, konfigurasi atau komposisi garis atau warna, atau garis dan warna atau gabungan keduaya,bentuk konfigurasi atau komposisi tersebut harus berbentuk tiga dimensi atau dua dimensi, bentuk tersebut harus pula memberikan kesan estetis, kesemuanya itu harus dapat dipakai untuk menghasilkan suatu produk, barang, komoditas industri, atau kerajinan tangan
\end{abstract}

Kata Kunci : UU No. 31 tahun 2000, Produk. 


\section{A. INTRODUCTION}

Berdasarkan undang-undang ini, perlindungan suatu desain diberikan untuk bentuk fitur-fitur bentuk, konfigurasi, atau komposisi garis dan warna, atau kombinasinya yang diterapkan pada suatu produk atau barang, baik yang bersifat untuk rumah tangga, ornamental, utilitarian atau industri merupakan contoh produkproduk atau barang dimana suatu desain industri dapat diterapkan.

Bagaimana dengan suatu desain grafis,apakah desain grafis tersebut juga dapat di lindungi dengan UU No.31 tahun 2000 tentang desain industri, karena mengingat pernah para pengusaha desain grafis contoh saja pengusaha Clothing Company di kota Bandung yang tidak mendaftarkan desain grafis pada kaosnya maka ia akan lemah untuk perlindungan hukumnya.

Suyatno mendefinisikan desain grafis sebagai, "Aplikasi dari keterampilan seni dan komunikasi untuk kebutuhan bisnis dan industri”, sebab karya desain grafis pada hakikatnya merupakan buah pikir dari serangkaian proses kreatif setelah melalui beberapa tahap layout secara komperhensif. Karya desain biasanya identik dengan stlye seseorang dalam menghasilakan karya, yang tidak lain merupakan produk kekayaan intelektual pendesain yang patut untuk di lindungi. Hak-hak atas kekayaan intelektual sebagai produk hukum disisi lain berupaya melindungi produk grafis atas penciptaan sorang pendesain melalui perangkat UU No.31 tahun 2000 tentang desain industri.

\section{B. CONTENT}

Menurut ketentuan pasal 1 ayat (1) UU No. 31 tahun 2000 tentang desain industri yang dimaksud dengan desain Industri ialah suatu kreasi tentang bentuk, konfigurasi, atau komposisi garis atau warna, atau garis dan warna, atau gabungan daripadanya yang berbentuk tiga dimensi atau dua dimensi yang memberikan kesan estetis dan dapat diwujudkan dalam pola tiga dimensi atau dua dimensi serta dapat dipakai untuk menghasilkan suatu produk, barang, komoditas industri, atau kerajinan tangan.

Merujuk pada definisi diatas maka, karakteristik desain industri itu dapat dirumuskan sebagai berikut :

1. Suatu kreasi tentang bentuk, konfigurasi atau komposisi garis atau warna, atau garis dan warna atau gabungan keduaya

2. Bentuk konfigurasi atau komposisi tersebut harus berbentuk tiga dimensi atau dua dimensi

3. Bentuk tersebut harus pula memberikan kesan estetis

4. Kesemuanya itu harus dapat dipakai untuk menghasilkan suatu produk, barang, komoditas industri, atau kerajinan tangan

Berdasarkan undang-undang ini, perlindungan suatu desain diberikan untuk bentuk fitur-fitur bentuk, konfigurasi, atau komposisi garis dan warna, atau kombinasinya yang diterapkan pada suatu produk atau barang, baik yang bersifat untuk rumah tangga, ornamental, utilitarian atau 
industri merupakan contoh produkproduk atau barang dimana suatu desain industri dapat diterapkan.

Menurut pasal 2 UU No.31 thun 2000 tentang Desain Industri, yang mendapat perlindungan desain industri ialah :

1) Hak Desain Industri diberikan untuk Desain industri baru

2) Desain Industri dianggap baru apabila pada tanggal penerimaan, desain industri tersebut tidak sama dengan pengungkapan yang telah ada sebelumnya

3) Pengungkapan sebelumnya, sebgaimana dimaksud dalam ayat (2) adalah pengungkapan desain industri yang sebelum :

a. Tanggal penerimaan;atau

b. Tanggal prioritas apabila permohonan diajukan dengan prioritas; telah diumumkan atau digunakan di Indonesia atau diluar Indonesia

Dalam pasal 3 UU No.31 tahun 2000 tentang desain industri dijelaskan bahwa suatu desain industri tidak dianggap telah diumumkan apabila dalam jangka waktu paling lama 6 (enam) bulan sebelum tanggal penerimaannya, desain industri tersebut :

a. Telah dipertunjukan dalam suatu pameran nasionak maupun internasional di indonesia atau di luar indonesia yang resmi atau diakui resmi;atau

b. Telah digunakan di Indonesia oleh pendesain dalam rangkapercobaan dengan tujuan pendidikan,penelitian dan pengembangan

Subyek dalam desain industri adalah pendesain atau yang menerima hak tersebut dari pendesain. Pendesain menurut ketentuan pasal 1 ayat (2) UU No.31 tahun 2000 tentang desain industri dalah seorang atau beberapa orang yang menghsilkan suatu desain industri. Perlindungan desain industri dapat di peroleh melalui sistem pendaftaran, dimana seorang pendesain memperoleh perlindungan hukum atas karyanya atau memperoleh hak desain industri apabila pihaknya telah mendaftarkan karya desainnya tersebut pada Direktorat Jendral HKI sesuai dengan ketentuan-ketentuan yang berlaku pada pada UU No.31 tahun 2000 tentang desain industri.

Contoh produk yang mendapat perlindungan dari UU No. 31 tahun 2000 tentang desain industri adalah produk-produk dari desain grafis, desain interior dan segala produk yang memenuhi kriteria unsur-unsur dari desain industri.

Dalam pembahasan sebelumnya diatas, Suyatno mendefinisikan desain grafis sebagai, "Aplikasi dari keterampilan seni dan komunikasi untuk kebutuhan bisnis dan industri”, sebab karya desain grafis pada hakikatnya merupakan buah pikir dari serangkaian proses kreatif setelah melalui beberapa tahap layout secara komperhensif. Karya desain biasanya identik dengan stlye seseorang dalam menghasilakan karya, yang tidak lain merupakan produk kekayaan intelektual pendesain yang patut untuk di lindungi. Hak-hak atas kekayaan intelektual sebagai produk hukum disisi lain berupaya melindungi produk grafis atas penciptaan sorang pendesain melalui perangkat UU No.31 tahun 2000 tentang desain industri. 


\section{CONCLUSION}

Dari penjelasan dalam pembahasan diatas maka dapat ditarik beberapa kesimpulan diantaranya :

1. Menurut pasal 2 UU No.31 thun 2000 tentang Desain Industri, yang mendapat perlindungan desain industri ialah :

1) Hak Desain Industri diberikan untuk Desain industri baru

2) Desain Industri dianggap baru apabila pada tanggal penerimaan, desain industri tersebut tidak sama dengan pengungkapan yang telah ada sebelumnya

3) Pengungkapan sebelumnya, sebgaimana dimaksud dalam ayat (2) adalah pengungkapan desain industri yang sebelum :

a. Tanggal penerimaan;atau

b. Tanggal prioritas apabila permohonan diajukan dengan prioritas; telah diumumkan atau digunakan di Indonesia atau diluar Indonesia

Dalam pasal 3 UU No.31 tahun 2000 tentang desain industri dijelaskan bahwa suatu desain industri tidak dianggap telah diumumkan apabila dalam jangka waktu paling lama 6 (enam) bulan sebelum tanggal penerimaannya, desin industri tersebut

a. Telah dipertunjukan dalam suatu pameran nasionak maupun internasional di indonesia atau di luar indonesia yang resmi atau diakui resmi;atau

b. Telah digunakan di Indonesia oleh pendesain dalam rangkapercobaan dengan tujuan pendidikan,penelitian dan pengembangan
2. Contoh produk yang mendapat perlindungan dari UU No. 31 tahun 2000 tentang desain industri adalah produk-produk dari desain grafis, desain interior dan segala produk yang memenuhi kriteria unsur-unsur dari desain industri. Berdasarkan pengertian desain idustri dalam pasal 1 ayat (1) UU No.31 tahun 2000 tentang desain industri maka karakteristik desain industri dapat dirumuskan sebagai berikut :

a. Suatu kreasi tentang bentuk, konfigurasi atau komposisi garis atau warna, atau garis dan warna atau gabungan keduaya

b. Bentuk konfigurasi atau komposisi tersebut harus berbentuk tiga dimensi atau dua dimensi

c. Bentuk tersebut harus pula memberikan kesan estetis

d. Kesemuanya itu harus dapat dipakai untuk menghasilkan suatu produk, barang, komoditas industri, atau kerajinan tangan

Misalnya : desain grafis dalam pembuatan gamabar kaos itu dapat di lindungi oleh UU desain industri.

\section{DISCUSSION}

Hasil Diskusi dari Materi ini Ialah Peraturan perundang undangan tentang desain industri yaitu desain grafis di lindungi oleh UU No.31 tahun 2000 tentang desain industri, karena desain grafis merupakan aplikasi dari keterampilan seni dan komunikasi untuk kebutuhan bisnis dan industri, sebab karya desain grafis pada hakikatnya merupakan buah pikir dari serangkaian proses kreatif setelah 
melalui beberapa tahap layout secara komperhensif. Karya desain biasanya identik dengan stlye seseorang dalam menghasilakan karya, yang tidak lain merupakan produk kekayaan intelektual pendesain yang memenuhi unsur-unsur atau karakteristik dalam pengertian desain industri yang tercantum dalam pasal 1 ayat (1) UU No.31 tahun 2000 tentang desain industri, maka dari itu desain grafis lebih pantas di lindungi melalui UU No.31 tahun 2000 tentang desain industri, meski ada kerancuan dengan UU No. 19 tahun 2002 tentang hak cipta, namun kurang tepat rasanya jika desain grafis dimasukan dalam hak cipta karena berlaku asas lex spesialis derograt lex generalis, bahwa peraturan yang khusus mengesampingkan peraturan yang bersifat umum.

\section{E. REFERENCE}

[1] O. M. Febriani and A. S. Putra, "Sistem Informasi Monitoring Inventori Barang Pada Balai Riset Standardisasi Industri Bandar Lampung," J. Inform., vol. 13, no. 1, pp. 90-98, 2014.

[2] A. S. Putra, "Paperplain: Execution Fundamental Create Application With Borland Delphi 7.0 University Of Mitra Indonesia," 2018.

[3] A. S. Putra, "2018 Artikel Struktur Data, Audit Dan Jaringan Komputer," 2018.

[4] A. S. Putra, "ALIAS MANAGER USED IN DATABASE DESKTOP STUDI CASE DB DEMOS."
"COMPREHENSIVE SET OF PROFESSIONAL FOR DISTRIBUTE COMPUTING."

[6] A. S. Putra, "DATA ORIENTED RECOGNITION IN BORLAND DELPHI 7.0."

[7] A. S. Putra, "EMBARCADERO DELPHI XE 2 IN GPUPOWERED FIREMONKEY APPLICATION."

[8] A. S. Putra, "HAK ATAS KEKAYAAN INTELEKTUAL DALAM DUNIA TEKNOLOGY BERBASIS REVOLUSI INDUSTRI 4.0."

[9] A. S. Putra, "IMPLEMENTASI PERATURAN

PERUNDANGAN UU. NO 31

TAHUN 2000 TENTANG

DESAIN INDUSTRI

BERBASIS INFORMATION TECHNOLOGY."

[10] A. S. Putra, "IMPLEMENTATION OF PARADOX DBASE."

[11] A. S. Putra, "IMPLEMENTATION OF TRADE SECRET CASE STUDY SAMSUNG MOBILE PHONE."

[12] A. S. Putra, "IMPLEMENTATION

PATENT FOR APPLICATION WEB BASED CASE STUDI WWW. PUBLIKLAMPUNG. COM."

[13] A. S. Putra, "IMPLEMENTATION SYSTEM FIRST TO INVENT IN DIGITALLY INDUSTRY."

[14] A. S. Putra, "MANUAL REPORT \& INTEGRATED DEVELOPMENT ENVIRONMENT BORLAND DELPHI 7.0." 
[15] A. S. Putra, "PATENT AS RELEVAN SUPPORT RESEARCH."

[16] A. S. Putra, "PATENT FOR RESEARCH STUDY CASE OF APPLE. Inc."

[17] A. S. Putra, "PATENT PROTECTION FOR APPLICATION INVENT."

[18] A. S. Putra, "QUICK REPORT IN PROPERTY PROGRAMMING."

[19] A. S. Putra, "REVIEW CIRCUIT LAYOUT COMPONENT

REQUIREMENT ON ASUS NOTEBOOK."

[20] A. S. Putra, "REVIEW TRADEMARK PATENT FOR INDUSTRIAL TECHNOLOGY BASED 4.0."

[21] A. S. Putra, "TOOLBAR COMPONENT PALLETTE IN OBJECT ORIENTED PROGRAMMING."

[22] A. S. Putra, "WORKING DIRECTORY SET FOR PARADOX 7."

[23] A. S. Putra, "ZQUERY CONNECTION IMPLEMENTED

PROGRAMMING STUDI CASE PT. BANK BCA Tbk."

[24] A. S. Putra, D. R. Aryanti, and I. Hartati, "Metode SAW (Simple Additive Weighting) sebagai Sistem Pendukung Keputusan Guru Berprestasi (Studi Kasus: SMK Global Surya)," in Prosiding Seminar Nasional Darmajaya, 2018, vol. 1, no. 1, pp. 85-97.

[25] A. S. Putra and O. M. Febriani, "Knowledge Management Online Application in PDAM
Lampung Province," in Prosiding International conference on Information Technology and Business (ICITB), 2018, pp. 181-187.

[26] A. S. Putra, O. M. Febriani, and B. Bachry, "Implementasi Genetic Fuzzy System Untuk Mengidentifikasi Hasil Curian Kendaraan Bermotor Di Polda Lampung," SIMADA (Jurnal Sist. Inf. dan Manaj. Basis Data), vol. 1, no. 1, pp. 21-30, 2018.

[27] A. S. Putra, H. Sukri, and K. Zuhri, "Sistem Monitoring Realtime Jaringan Irigasi Desa (JIDES) Dengan Konsep Jaringan Sensor Nirkabel," IJEIS (Indonesian J. Electron. Instrum. Syst., vol. 8, no. 2, pp. 221-232.

[28] D. P. Sari, O. M. Febriani, and A. S. Putra, "Perancangan Sistem Informasi SDM Berprestasi pada SD Global Surya," in Prosiding Seminar Nasional Darmajaya, 2018, vol. 1, no. 1, pp. 289-294. 